\section{www.czasopisma.pan.pl \\ ARCHIVES \\ of

\title{
Improvement of Artistic Cast Production System
}

\author{
R. Władysiak ${ }^{a, *}$, T. Pacyniak ${ }^{a}, J$. Trzoska ${ }^{b}$ \\ ${ }^{a}$ Department of Materials Engineering and Production Systems, Lodz University of Technology, \\ 1/15 Stefanowskiego Street, 90-924 Lodz, Poland \\ ${ }^{\mathrm{b}}$ Gliwickie Zakłady Urządzeń Technicznych GZUT S.A., 2 Robotnicza Street, 44-100 Gliwice, Poland \\ *Corresponding author. E-mail address: ryszard.wladysiak@p.lodz.pl
}

Received 07.06.2017; accepted in revised form 27.07.2017

\begin{abstract}
The paper presents the technology and organization of the artistic cast production. On the basis of the actual cast production system, the manufacturing process was shown, in particular sand-piece moulding, which is a very important process and a time-consuming part of the entire manufacture of the casts. The current state of the production process as well as the organization of the work and production technology were analysed with the use of methods and techniques of production improvement, the Lean Manufacturing concept and computer systems. The results of the analysis and studies were shown with use of schemes and graphs of the layout of the production resources, a flow chart of the production process, value stream mapping, and a costs table for the production and modernization of the moulding stage. The work has shown that there are possibilities to improve the artistic cast production system. This improvement leads to increased productivity, lower production costs of artistic casts and increased competitiveness of the foundry.
\end{abstract}

Keywords: Artistic casting, Sand-piece moulding, Improvement, Lean manufacturing

\section{Introduction}

Artistic casting involves moulding and casting of a product made of metal or another material that is a work of art or craft [1]. Several groups of artistic casts can be distinguished: emblems, figurines, statues, vases, medals, monuments, busts, memorial plaques, bas-reliefs, as well as artistic and utilitarian fancy-goods. The complicated construction of the models of these casts requires the use of multi-part casting moulds with a complex division surface. Sand-piece moulding (Fig. 1) is one of the methods which make such casting possible. In this method, the casting mould is made up of a number of hand-crafted sand-pieces arranged side by side on the surface of the pattern. An integral part of sand-piece moulding is the pattern match moulding process. The pattern match is an auxiliary mould that helps in determining the mould joint of irregular and non-split patterns. It also acts as a pattern board. The pattern match is eliminated at a specific stage of casting mould preparation; it does not participate in the filling of the mould with the liquid metal.

The main stages of the sand-piece moulding process are: preparing the pattern, making a pattern match, moulding sandpieces on the pattern match, making the drag, making the cope, moving up the cope, fitting sand-pieces in the cope, making the core, drying the mould, repairing the dried moulds, assembling the mould, filling the mould, knocking out the casts, cleaning the casts, joining individual casts, carving and patinating.

The Lean Manufacturing (LM) concept is a frequently used and very effective method of continuously improving productivity, shortening the production cycle of a product and eliminating the waste produced during the manufacturing process [3-9]. The idea of lean production is a lower, compared to the traditional one, consumption of all the production factors and a high degree of utilization of the production capacity. 


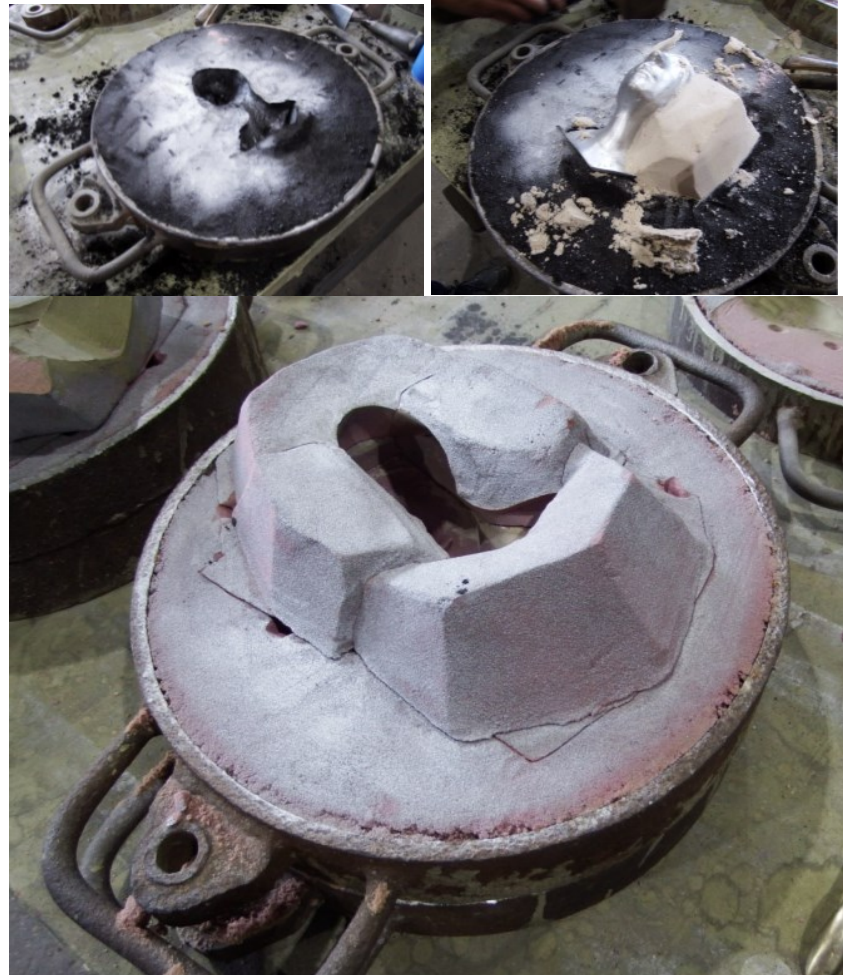

Fig. 1. Selected stages of moulding process: pattern batch, sandpiece, drag - lower part of mould [2]

It leads to the production of more and more products with a lower consumption of the enterprise resources. The concept of improvement also involves the use of new ecological manufacturing technologies for moulds and casting alloys, as well as improvement of the production organization [10-13].

\section{Work methodology}

The results of the investigation of the artistic cast production system presented in the paper were obtained under the actual conditions of the GZUT Foundry in Gliwice. The foundry produces mainly industrial casts made of grey and spheroidal cast iron as well as bronzes, of the sizes $0,3 \div 2000 \mathrm{~kg}$, and also artistic casts made of bronze cast iron, both small and very large assembled from parts.

The analysis of the actual state of the production system was performed by way of interviewing the management and the employees, taking working day snapshots and preparing experimental moulds (Fig. 1). The work was based on a detailed analysis of the process of producing several bust and statute casts by means of the sand piece moulding method and with the use of cores. The casts were moulded in sets of rectangular boxes with the dimensions of $800 \div 1600 \mathrm{~mm}$, as well as round boxes. The analyses also utilized the information collected owing to the rich experience of the foundry in the scope of previously produced artistic casts. Also, the possibilities of improving the organization of the production in the examined department within the concept of the development of the whole enterprise were analysed.

The sand-piece moulding process was analysed with special care because it is an essential part of the manufacturing process.

The Lean Manufacturing, Project Management and CAD concepts were used in the analysis and design for the organizational and technological improvement of the production system.

The artistic cast manufacturing process was visualized by means of: production resource layout schemes, manufacturing process diagrams, Value Stream Mapping (VSM) charts, and Gantt diagrams. The assessment of the effectiveness of the proposed changes was performed by way of estimating the main investment costs of the required production equipment and the impact of the latter on the change in the yield and cost of the casting production.

\section{Findings of investigation}

The analysis of the production system shows that the main production resources include: a team of 4 employees working on single shift days, a moulding workshop of $11 \times 30 \times 5 \mathrm{~m}$, two moulding sand-mixers with the capacities of $250 \mathrm{~kg} / \mathrm{h}$ and 500 $\mathrm{kg} / \mathrm{h}$, a crane with the lifting capacity of up to 5 tons, buckets for metering the moulding components, a wheelbarrow as a means of transport between each station, six sets of supports for the forming table or the moulding boxes, a table and shelves for storing the necessary materials and moulding tools. It should be emphasized that the employed workers have high qualifications confirmed by their long professional experience as artistic cast moulders. Their participation begins already at the stage of establishing the possibilities, time and costs of fulfilling the client's demands and next performing by each worker all the stages of the production process, elaborating the technological concept, until the mould and the cast are produced.

Figures 2 and 3 show the layout of the analysed production resources and a diagram of the artistic cast manufacturing process. The presented process (Fig. 3) is a complex multi-stage process. There are many relations between the individual subprocesses (operations) that are executed in a serial manner. The beginning of the subsequent subprocess (operation) is related to the completion of the preceding operation. The efficiency of the casting process can be significantly affected by the quality defects of the individual mould elements, such as poor relief of the sandpieces, uneven compression of the clay cones or mould defects discovered after the drying process. Therefore, before proceeding to the next moulding stage, all the defects and irregularities must be removed by way of: rendering the relief of the tricks, repeating the application of upper half of the mould, or repairing the defects of the mould.

The length and complexity of the production process, the number of stages and the duration of the process are determined primarily by the size and complexity of the cast. The main factors that increase the difficulty of casting include the number of cast parts, the type of technology used, the need for cores, the number of cores, and the variety of the moulding and core sand required.

These factors cause the need for additional processes. For example, quartz-clay moulds require drying and additional control. The use of heat-hardening and chemo-hardening binders 
allows the process to be shortened by eliminating the timeconsuming stage of mould drying. The reconstruction of the inner surfaces of an artistic cast requires the preparation of the core, while casting in parts requires the operation of joining (welding) the elements into a complete product and additional chisel work on the surfaces of these joints (welds).

From the analysis of the production cycle, it is clear that the process of drying the moulds, their inspection and possible repairs is the most time-consuming step of the moulding process. In addition, the moulding requires multiple reworking of the required portions of the suitable moulding sand necessary for the execution of the main moulding processes. One of the most labour-consuming processes is making the core of the cast.

It consists of core grid preparation, core and coke preparation, core compacting, and multiple overlays of the cope of the mould.

The analysis of the displacement of workers at the work place shows that they frequently move between the same work positions.

The project aiming to improve the organization of the production of artistic casts consists in modernization of the moulding hall by way of designing the main manufacturing cell and the work stations. Inside the manufacturing cell is a batch-mixer with a spreader arm, which is positioned in the shape of the letter "U". The latter is formed by the ball feeder and the main work stations: making of sand-pieces, pattern match moulding, the drag moulding, the cope moulding as well as assembly of the core grid and core compacting process. This is a group of positions that require the use of moulding sand or core sand. Designated auxiliary workstations are used to prepare a pattern, a stalk or a hook of sand-piece and a core grid. This makes it possible to separate the duties between the employees, so that the entire team is evenly involved in the production process. Each moulder working in the cell is equipped with a mobile trolley, which contains all the tools needed for the job.
Each station of the cell is adapted to work with two moulders simultaneously. The mould bay was also equipped with a lower capacity mixer, designed to produce smaller forms of artistic casts.

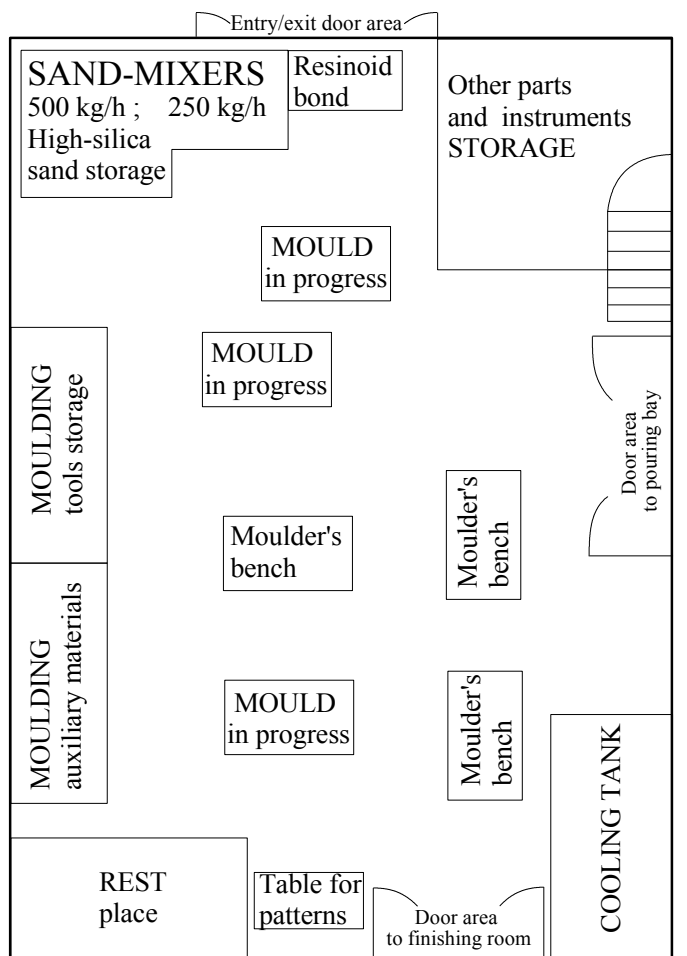

Fig. 2. Moulding bay floor plan layout - present state

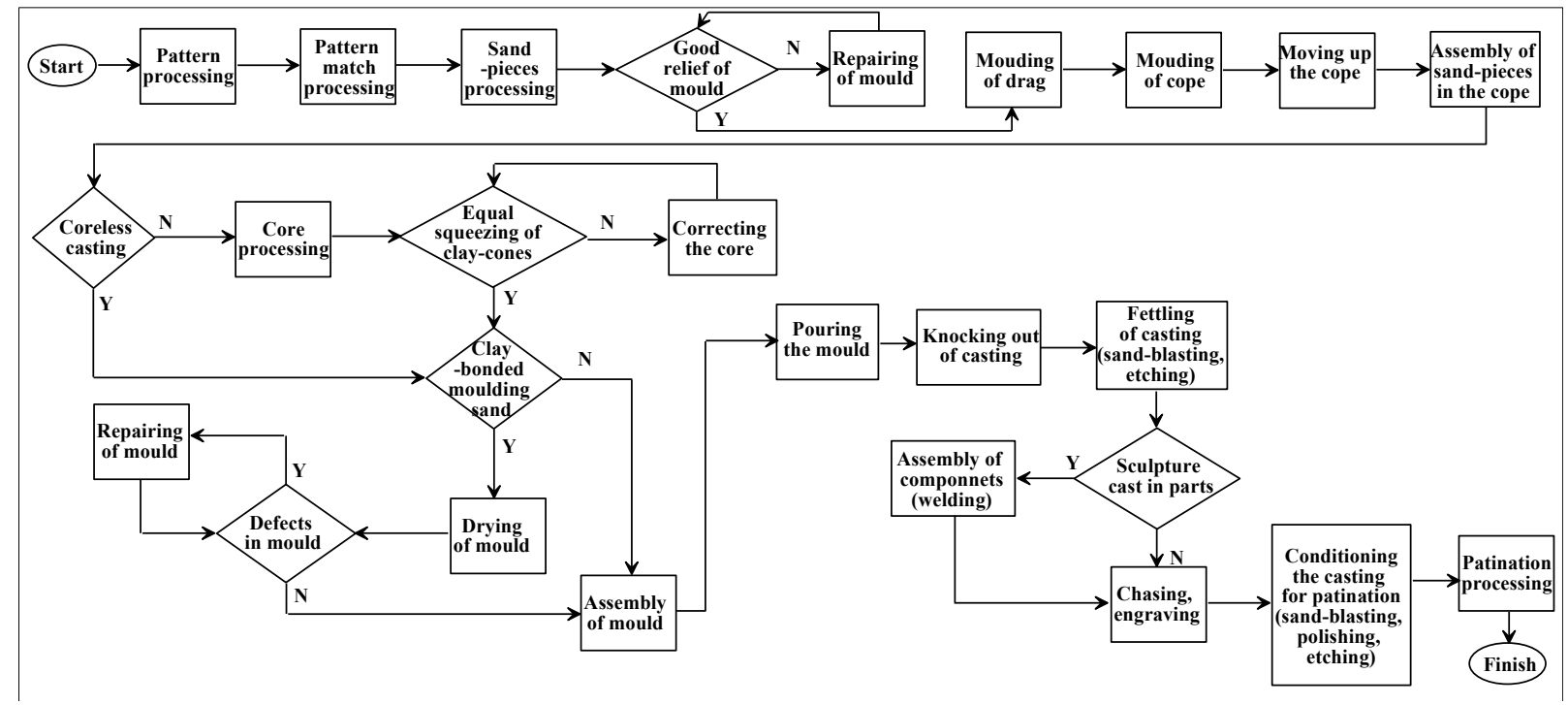

Fig. 3. Flow chart of the manufacturing process of an artistic cast

Figure 4 shows the design of a new layout of production resources in the moulding bay. The reorganization of the area excludes the unnecessary movements and activities. The optimization of the working time through the removal of this type of waste will 
increase the productivity of the employees, while not reducing the quality of the manufactured casts. All the workstations should be designed and standardized according to the $5 \mathrm{~S}$ method.

Improving the artistic cast manufacturing technology requires a complete elimination of quartz-clay sands and replacing them with self-hardening sands or self-hardening resin binder sands. This will eliminate the long process of mould drying and the control and repair of moulds and cores.

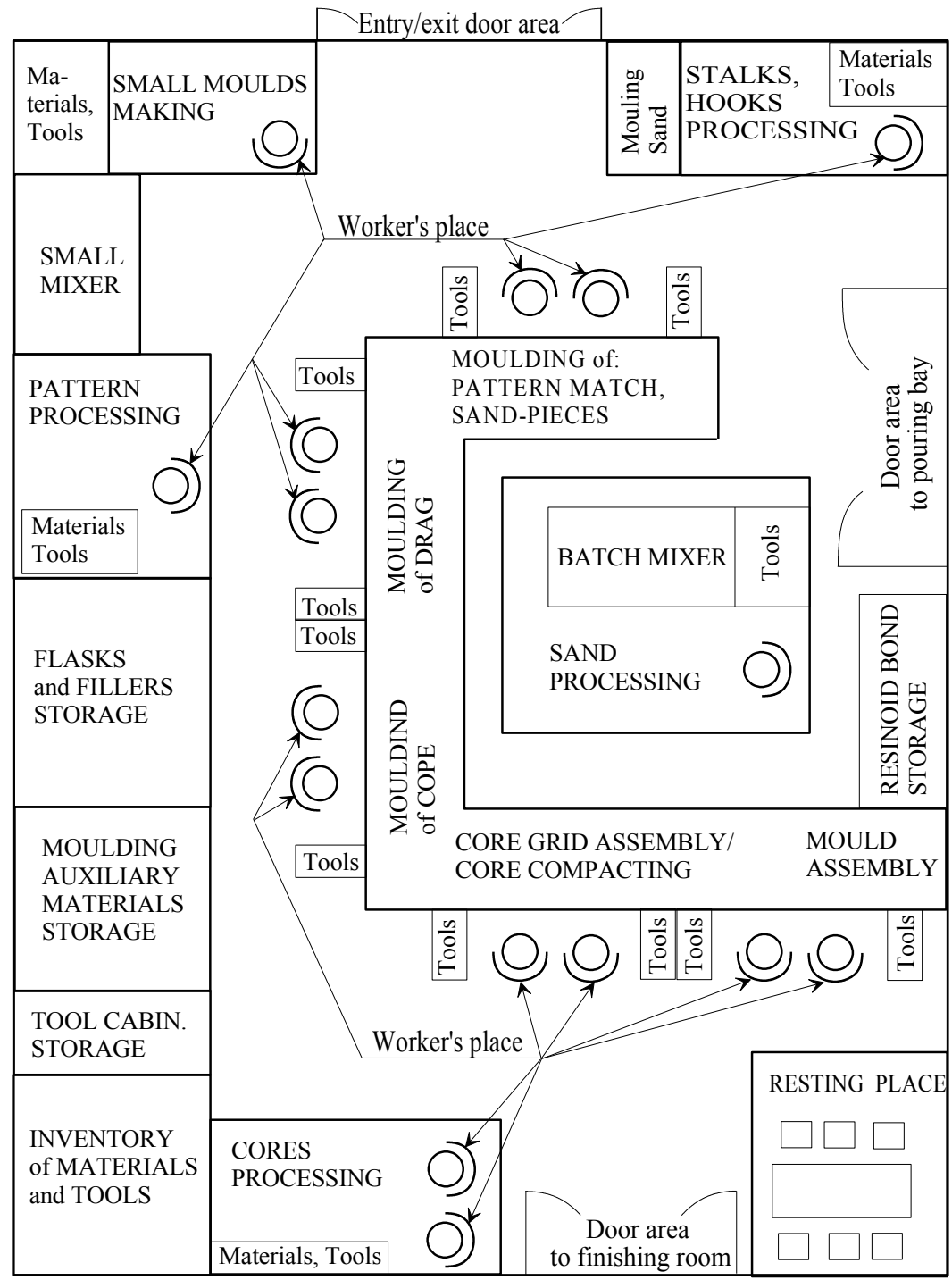

Fig. 4. Moulding bay floor plan layout - future state

Based on the proposed reorganization of the moulding bay, a map of the future state of the value stream was created. It presents a new organization of employees through assigning specific tasks and responsibilities to them. At the same time, it eliminates duplication of the waiting time before the preparation of the moulding sands or other materials as well as tools necessary for the work. In addition, the locations of the flow of materials from different processes are equipped with supermarkets which collect the components used for the main production processes.

The VSM analysis shows that, in the current value stream, the execution of many operations and technological processes is preceded by a waiting time. In most cases, this refers to the time required to prepare the foundry moulds and to organize the materials or tools necessary for the work. The total waiting time is 4.6 days and is one of the main sources of waste compared to 10.7 days (4810 minutes) of the operating time needed to produce an artistic cast. You can also notice the variable number of operators performing the process and the large disparities in the duration of each process. All these elements significantly affect the total time of producing an artistic cast.

Figures 5, 6 and 7 show the future state of the map of the value stream and the Gantt charts of the improved manufacturing process, respectively. The Gantt charts show that the moulding time is about 3.5 days and the entire manufacturing process has been reduced by about 3.3 days. 


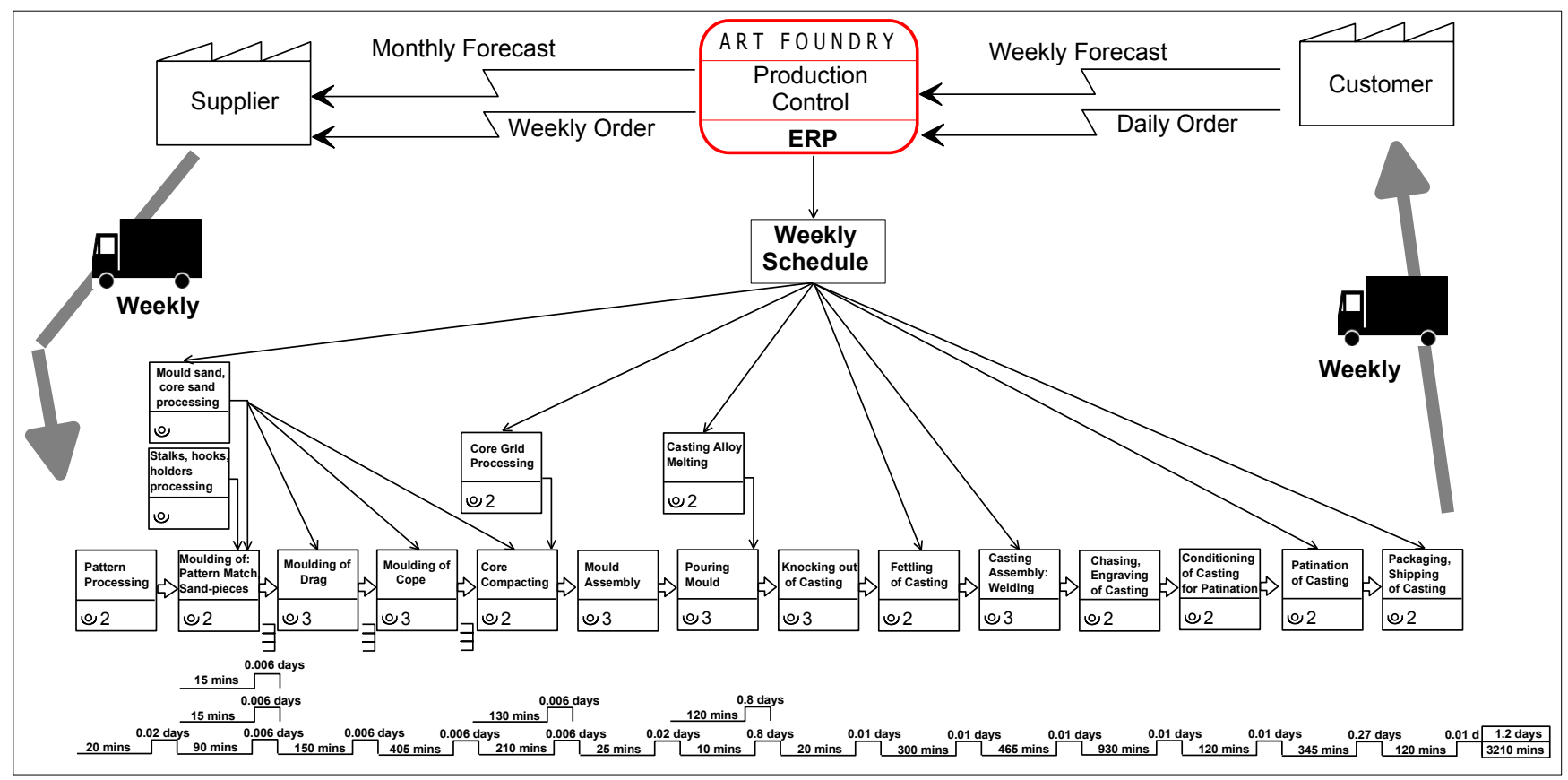

Fig. 5. Map of value stream - future state

\begin{tabular}{|c|c|c|c|c|c|c|c|c|}
\hline & Name & ${ }^{0}$ Mon 8 & 16 Wed 2 & $\begin{array}{l}\text { Operat } \\
24\end{array}$ & $\begin{array}{l}\text { ion tim } \\
2 \quad \text { Fri }\end{array}$ & 10, $\mathrm{h}$ & 48 Tue & 56 Wed 64 \\
\hline $\mathbf{1}$ & Moulding the Sand-pieces & 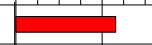 & & & & & & \\
\hline 2 & Making the Core & $\square$ & & & & & & \\
\hline 3 & Mould Assembly & & I & & & & & \\
\hline 4 & Pouring the Mould & & 1 & & & & & \\
\hline 5 & Knocking out of Casting & & I & & & & & \\
\hline 6 & Fettling of Casting & & 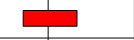 & & & & & \\
\hline 7 & Finishing the Casting, Chiseling, Engraving & & $\square$ & & & a & & \\
\hline 8 & Patination of Casting & & & & & & 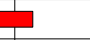 & \\
\hline 9 & Packaging the Casting & & & & & & $\square$ & \\
\hline 10 & Dispatching the Casting & & & & & & $\square$ & \\
\hline
\end{tabular}

Fig. 6. Gantt chart of manufacturing process - future state

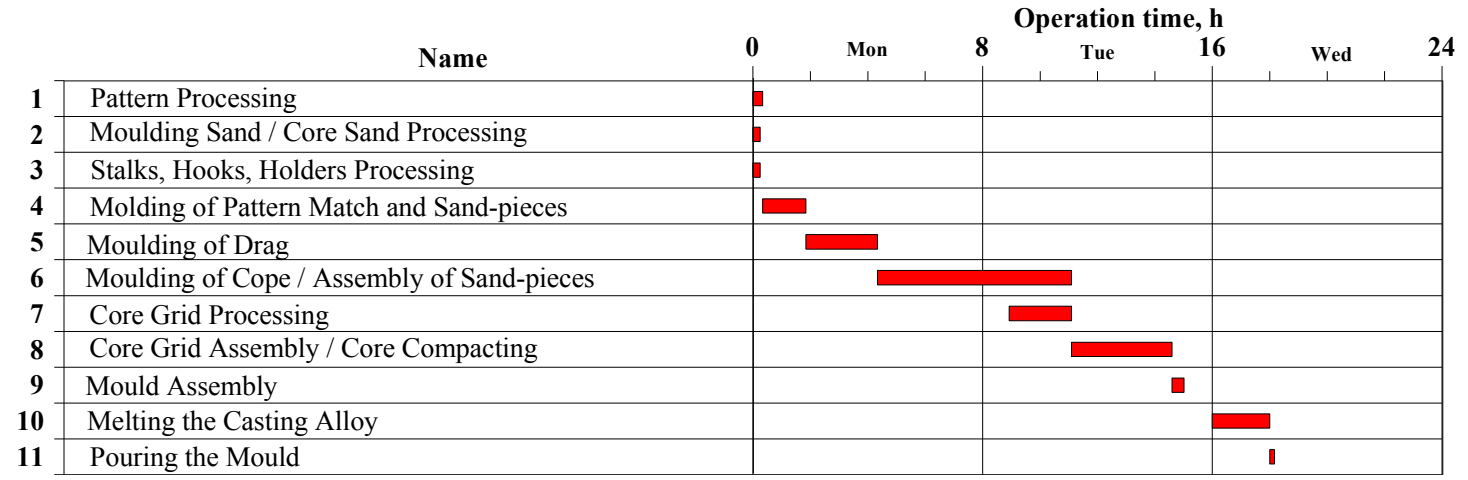

Fig. 7. Gantt chart of moulding process - future state

The presented technological and organizational solution to improve the casting system requires the purchase of the necessary machines, tools and materials. The total cost of the investment is estimated at $\sim 600,000$ PLN. Among the most cost-consuming items are the following: moulding sand mixer and batch mixer $(\sim$ 400000 PLN), materials handling equipment ( 20000 PLN), 
transport equipment $(\sim 18,000$ PLN $)$, hand and pneumatic moulding tools $(\sim 20000$ PLN $)$ and equipment for the improvement of environmental parameters (ventilation, lighting ( 100000 PLN).

Table 1 shows a comparison of the present and future manufacturing costs, assuming the distribution of the total costs of the investment over a period of 5 years and a $50 \%$ increase in the cast production efficiency.

Table 1.

Estimated costs of moulding process

\begin{tabular}{lcccc} 
& Present & Future & Present & Future \\
\cline { 2 - 5 } & \multicolumn{2}{c}{ Monthly, PLN } & \multicolumn{2}{c}{ 1 cast, PLN } \\
\hline Salary & \multicolumn{2}{c}{20400} & 10200 & 6800 \\
\hline $\begin{array}{l}\text { Moulding bay } \\
\text { maintenance }\end{array}$ & \multicolumn{2}{c}{5000} & 2500 & 1667 \\
\hline Materials & 3315 & 4973 & 1658 & 1658 \\
\hline Depreciation & - & 10000 & - & 3333 \\
\hline Total & $\mathbf{2 8 7 1 5}$ & $\mathbf{4 0 3 7 3}$ & $\mathbf{1 4 3 5 8}$ & $\mathbf{1 3 4 5 7}$ \\
\hline
\end{tabular}

To sum up the performed studies (Table 2), the design changes in the production system can increase the productivity of moulds and casts and also reduce the casting cost by about $30 \%$ after the depreciation time. The monthly production costs in the new production system will increase by approximately $6 \%$ as a result of increased productivity and material consumption.

Table 2.

Change of efficiency of production system

\begin{tabular}{ccc}
\hline & Present & Future \\
\hline Lead time of manufacturing, days & 15.3 & 8.6 \\
\hline Lead time of moulding process, days & 5.6 & 2 \\
\hline Number of casts - monthly, pcs & 2 & 3 \\
\hline
\end{tabular}

\section{Conclusions}

The conducted research and analyses show that artistic casts, following the reproduced sculptures, are characterized by a high degree of complexity. Their production requires a high level of professionalism, a lot of manual work, a varied number of mould and cast parts, and a large variety of materials. The uniqueness of these casts makes it difficult to standardize the stages of production. The system improvement project described in the paper is an attempt to improve the organization and technology dedicated mainly to the more frequently produced casts, such as memorial plaques and bas-reliefs, as well as busts and statues.
The increase in the production efficiency attained in this work should be interpreted more as a confirmation of the correctness of the presented directions for the improvement of the production system rather than an easy way of achieving a high profit from the production of artistic casts.

\section{References}

[1] Gawroński, J., Wojarski, T. (2007). Art Foundry. Forming and casting in Pieces. Gliwice: Silesian University Publishing House. (in Polish).

[2] Grzejszczak, M. (2017). Improvement of Technology and Organization of Artistic Castings Manufacturing with Use of Computer Systems. Unpublished M.Sc. dissertation. Lodz University of Technology.

[3] Szatkowski, K. (2014). Modern Production Management, Process Approach. Warszawa: PWN.

[4] Antosz K., Pacyna A. (2016). Lean Manufacturing. Improvement of production. Rzeszów: Rzeszow University of Technology Publishing House.

[5] Władysiak, R. (2006). Reengineering of Precision Casting production System. Archives of Foundry, 19, 413-424.

[6] Jezierski, J. \& Janerka, K. (2013). The Lean Manufacturing tools in polish foundries. Archives of Metallurgy and Materials. 58(3), 937-940.

[7] Prasad. S., Khanduja. D. \& Sharma, S.K. (2016). An empirical study on applicability of lean and green practices in foundry industry. Journal of Manufacturing Technology Management. 27, 408-426.

[8] Torielli, R.M., Abrahams, R.A., Smillie, R.W., Voigt, R.C. (2010). Using lean metodologies for economically and envirimentally sustainable foundries. 69th World Foundry Congress, 2, 710-726.

[9] Singh, V., Mani, V.G.S., Kollanus, J.(2010).Lean operations in a foundry trough a manufacturing oriented ERP software. 69th World Foundry Congress, 2, 791-797.

[10] Nadolski, M., Konopka, Z., Łągiewka, M. \& Zyska, A. (2010). Decorative Layers on Tin Bronzes, Archives of Foundry Engineering. 10(4), 153-156.

[11] Władysiak, R., Kozuń, A. \& Pacyniak, T. (2017). The Effect of Water Mist Cooling of Casting Die on the Solidification, Microstructure and Properties of AlSi20 Alloy. Archives of Metallurgy and Materials. 62(1), 187-194.

[12] Bydałek, A.W. (2006). The influence of nitride on the melting $\mathrm{Cu}-\mathrm{Al}$ alloys conductions. Metalurgija. 45(1), 41-44.

[13] Rapiejko, C., Pisarek, B. \& Pacyniak, T. (2017). Effect of intensive cooling of alloy AM60 with chromium and vanadium additions on cast microstructure and mechanical properties. Archives of Metallurgy and Materials. 62(1), 309314. 